Reprod. Nutr. Dévelop. 1980, 20 (1 A), 119-138.

\title{
Effects of lactose and mode of sterilization of a lactose diet on mineral metabolism in germ-free
} and conventional rats

\author{
par Claude ANDRIEUX, L. GUÉGUEN *, E. SACQUET \\ Laboratoire des Animaux sans Germes, CNRS \\ * Station de Recherches de Nutrition, INRA \\ 78350 jouy en Josas, France.
}

\begin{abstract}
Summary. Mineral balances of $\mathrm{Ca}, \mathrm{P}, \mathrm{Mg}, \mathrm{K}, \mathrm{Na}, \mathrm{Zn}, \mathrm{Mn}, \mathrm{Cu}$ were carried out on 6-week old Fisher rats for 14 consecutive days. Four lots of germfree (GF) and 4 lots of conventional $(\mathrm{CV})$ rats were fed a semi-synthetic diet at weaning containing either 0 or 10 p. 100 of lactose (L). The diet was sterilized either by irradiation (I) or by autoclave (Au). Lactose, when added to the diet, caused very variable modifications of the mineral metabolism, depending on the mineral studied and the mode of sterilization. Thus, retention and apparent absorption of iron were hardly changed by the presence of lactose. On the other hand, those of $\mathrm{Mn}$ were strongly enhanced by the lactose. The action of the other minerals was complex ; it was modulated either by the mode of diet sterilization, the flora, or by both factors simultaneously. The IL diet increased retention of most of the minerals ; in some cases $(\mathrm{Na}, \mathrm{Zn}, \mathrm{P}, \mathrm{Ca})$ it was only evidenced in $\mathrm{CV}$ rats ; in other cases $(\mathrm{Mn}, \mathrm{Mg}, \mathrm{Cu})$ its action was visible in both CV and GF animals. Steam-sterilized lactose (AuL) considerably reduced this effect and even reversed it. This change in lactose action under the effect of steam sterilization especially affected absorption, which declined for all the minerals, except $\mathrm{Zn}$ and $\mathrm{Mn}$. It was accompanied by a drop in the digestive efficiency ratio which was particularly pronounced in GF rats. The destruction of $1 / 3$ of dietary lactose by steam sterilization could not alone explain the differences between the effects of IL and AuL. Other factors, such as the products of the Maillard reaction formed by steam sterilization of the diet, might be implicated.
\end{abstract}

Carbohydrates, and particularly those such as lactose which are not readily absorbed, change mineral metabolism in conventional rats. In spite of some controversy, lactose has been shown to increase the absorption and retention of calcium in vivo and in vitro (Bergeim, 1926 ; Fournier, 1954 ; Fournier and Dupuis, 1964 ; Dupuis, 1957 ; Dupuis, Brun and Fournier, 1962 ; Lengemann, Wassermann, and Comar, 1959 ; Fournier and Dupuis, 1975 ; Armbrecht and Wasserman, 1976). This carbohydrate also enhances absorption and retention of manganese (Fournier and Fournier, 1972 ; Gruden, 1976), magnesium (Lengemann, 1959), iron (Bouvet, 1970), zinc (Fournier and Digaud, 1969) and cobalt (Fournier, Fournier and Digaud, 1974). 
Steam-sterilizing a lactose diet reduces the lactose content and forms Maillard reaction products, diversely affecting the nutritional physiology of the animals ingesting them. These substances affect food intake, reduce nitrogen digestion and cause hepatic degeneration, renal hypertrophy, allergies and reproductive ailments (Adrian, 1974 ; Adrian and Susbielle, 1975).

Lactose and Maillard reaction products are metabolized by the microbial flora of the digestive tract. Thus, the lactic acid formed by lactose fermentation modifies the microbial flora, reducing cellulose digestion or affecting some metabolisms such as that of bile salts (Wostmann ef al., 1976). Tanaka, Tung-Ching Lee and Chichester (1975) showed that premelanoidins could be metabolized by digestive tract flora and thus changed into absorbable products. In a recent study, we demonstrated that the mode of diet sterilization altered the metabolism of some minerals, and that most of the changes were more marked when there was no microbial flora.

In order to extend our knowledge of the relationships among microbial flora, sterilization of the diet, and mineral metabolism, we have studied the result of introducing 10 p. 100 of lactose into the diet before sterilization ; the data obtained have been compared with those from the previous study using a lactose-free diet (Andrieux, Guéguen and Sacquet, 1979).

\section{Material and methods.}

The diet composition, experimental animals and analytical methods were the same as in the previous study (Andrieux, Guéguen and Sacquet, 1979).

Two lots of germ-free (GF) rats and two of conventional (CV) rats, containing 8 to 9 animals each, were given a semi-synthetic diet at weaning (table 1 ) in which

TABLE I

Dief composition (p. 100)

\begin{tabular}{|c|c|}
\hline Maize starch $\ldots \ldots \ldots$ & 57,5 \\
\hline Casein $\ldots \ldots \ldots \ldots \ldots \ldots \ldots \ldots \ldots \ldots$ & 20,5 \\
\hline Maize oil $\ldots \ldots \ldots \ldots \ldots \ldots \ldots \ldots$ & 9 \\
\hline Cellulose $\ldots \ldots \ldots \ldots \ldots \ldots \ldots \ldots$ & 5 \\
\hline * Mineral compound ............... & 5 \\
\hline ** Additional vitamins and amino acids....... & 3 \\
\hline
\end{tabular}

* The mineral compound included (in $\mathrm{g} / \mathrm{kg}$ ) : calcium carbonate : 260 ; monocalcium phosphate : 200 ; dipotassium phosphate : 225 ; disodium phosphate : 100 ; sodium chloride : 100 ; magnesium sulfate : 75 ; iron citrate : 20 ; zinc sulfate : 10 ; manganese sulfate : 8.4 ; copper sulfate : 1.2 ; potassium iodide : 0.2 ; cobalt chloride : 0.2 .

The mineral composition of each preparation was controlled by assay. The complete diet contained a mean (in mg/g dry matter) of : Ca $9.9 ; \mathrm{P} 7.4 ; \mathrm{K} 5.2 ; \mathrm{Na} 3.1 ; \mathrm{Mg} 0.40 ; \mathrm{Mn} 0.27 ; \mathrm{Fe} 0.26$; Zn $0.19 ; \mathrm{Cu} 0.03$.

** For $100 \mathrm{~g}$ diet : retinol 800 U.I. ; cholecalciferol 100 U.I. ; $\alpha$ tocopherol acetate $150 \mathrm{mg}$; menaphthone $10 \mathrm{mg}$; thiamine $6 \mathrm{mg}$; nicotinic acid $5 \mathrm{mg}$; nicotinamide $5 \mathrm{mg}$; riboflavine $3 \mathrm{mg}$; pyridoxamine $0,4 \mathrm{mg}$; pantothenic acid (as calcium salt) $30 \mathrm{mg}$; biotin $0,1 \mathrm{mg}$; pteroylmonoglutamic acid $1 \mathrm{mg}$; p-aminobenzoic acid $5 \mathrm{mg}$; cyanocobalamin $25 \mu \mathrm{g}$; ascorbic acid $200 \mathrm{mg}$; myo-inositol $100 \mathrm{mg}$; methionine $300 \mathrm{mg}$; choline $200 \mathrm{mg}$. 
10 p. 100 of the starch was replaced by lactose. The dry diet was irradiated under vacuum to 4 megarads (IL diet). The steam sterilized diet (AuL diet) contained $20 \mathrm{~g}$ water $/ 100 \mathrm{~g}$ before it was sterilized at $120^{\circ} \mathrm{C}$ for $20 \mathrm{~min}$. After sterilization, the IL diet contained 10 p. 100 of lactose and the AuL ration 6.6 p. 100.

As previously, the mineral balance of the 4 lots of rats was determined between 6 and 8 weeks after birth. These results were compared to those of the former experiment in which 2 lots of GF rats and 2 of CV animals, containing 7 to 13 rats each, were given either an irradiated $(I)$ or steam-sterilized $(\mathrm{Au})$ lactose-free diet.

In the present study, we have compared 8 lots of rats : 4 lots fed a lactose-free diet (lots CVAu, CVI, GFAu, GFI), and 4 fed a lactose diet (CVAuL, CVIL, GFAuL, GFIL).

Expression of results. - To eliminate individual variations in body weight and feed intake, each result is presented in $\mathrm{mg}$ of minerals per $100 \mathrm{~g}$ of body weight on one hand, and in the percentage of the amount of mineral ingested on the other. The feed efficiency is represented by the percentage of the amount of dry diet ingested. Only the results which appeared similar in both the modes of expression were considered.

The GF rat caecum is very voluminous (10 p. 100 of the body weight) as compared to that of CV rats (2 p. 100 of the body weight). So, caecal weight had to be subtracted from body weight to avoid any systematic error when comparing the germ-free and conventional states.

The results are expressed by the mean \pm the standard deviation of the mean. Variance analysis to assess the data included three factors : flora (F), lactose (L), and mode of diet sterilization (S).

Emphasis has been placed on the most significant differences when discussing the results : the interaction of the three factors ( $F, L, S)$ when each modified the action of the two others ; a 2-factor interaction (F-L ; L-S ; F-S) when one factor changed the other independently of the third; the effect of a single factor $F, L$ or $S$ when its effect was dominant (Scheffe, 1959).

\section{Results.}

General characteristics of the animals, dry matter digestive efficiency (table 2).

The absence of microflora, the presence of lactose and, in the case of CV rats, steam sterilization, all increased caecal weight; the first factor had the greatest effect.

At the end of the experiment, rat body weight varied in a complex way according to the three factors. In rats fed the irradiated diet the presence of a flora and the absence of lactose tended to increase body weight, but in animals given the steam-sterilized died, the absence of lactose had a favorable effect only on CV rats and no effect on GF rats.

Weight gain during the balance period did not entirely paralell the body weight at the end of the experiment. Data on the amount of feed intake and the conversion factor thus have no general value. On the other hand, the differences were very clear for fecal excretion and apparent digestibility of the dry matter. This ratio varied more 


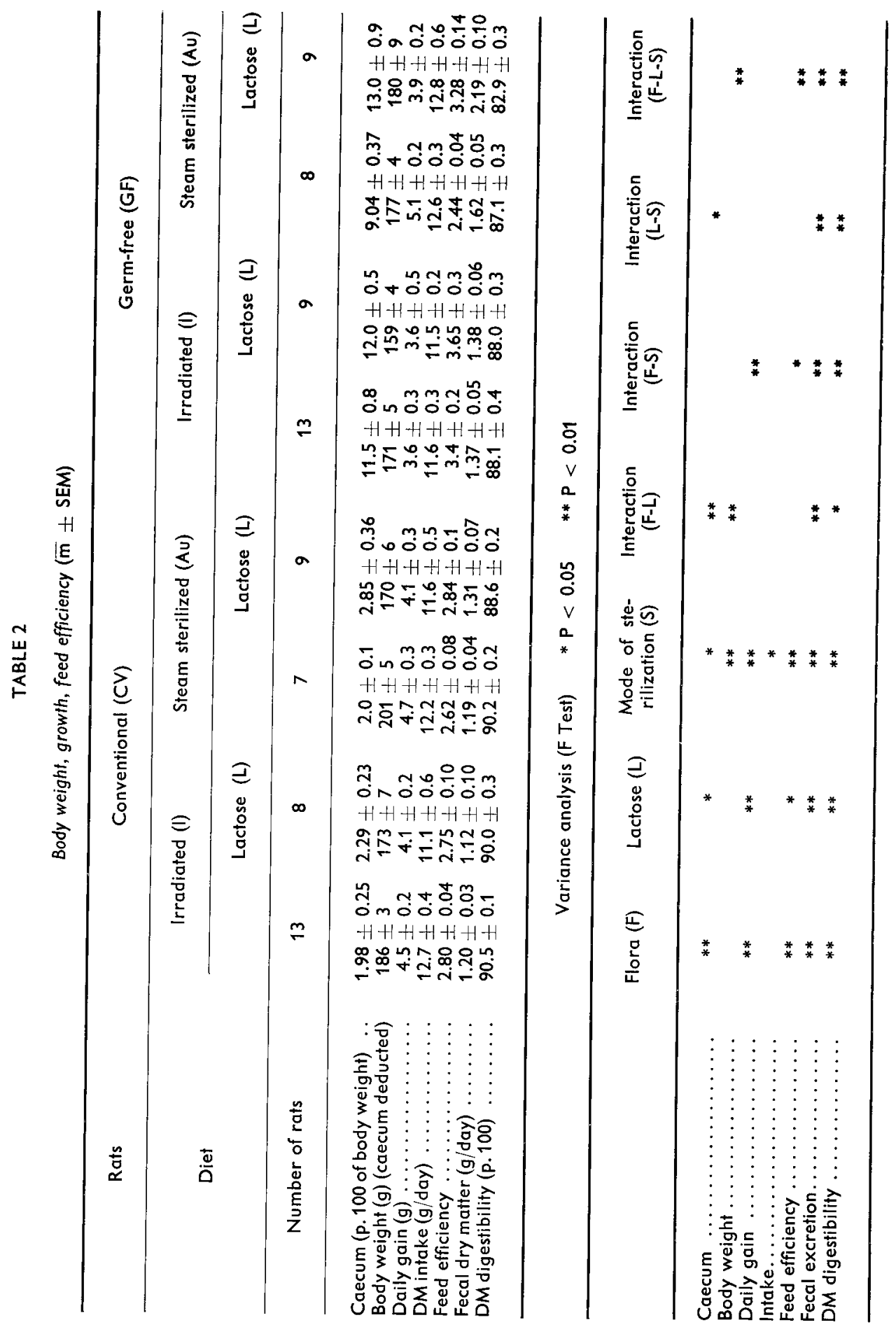


in relation to fecal excretion than to feed intake. The apparent digestibility of the dry matter was lower in GF than in CV rats, in those fed the Au diet than in animals given the I diet, and in those receiving lactose than in those given lactose-free diets. The greatest variation was that the presence of lactose did not alter diet digestibility in rats given the irradiated food, while it did decrease digestibility in those fed the Au diets. This digestibility decreased more in GF than in CV rats. The digestive tract flora thus somewhat palliated the drop in diet digestibility caused by steam sterilization of the lactose diet.

\section{Mineral balances.}

The data on mineral balance are given in tables 3 to 11. The changes caused by the three factors, flora $(F)$, lactose $(L)$ and mode of sterilization $(S)$, varied widely depending on the mineral element studied. These effects will be discussed element by element and in order of increasing complexity.

a) The retention and apparent absorption of iron were little changed by the presence of lactose. They increased slightly under the effect of lactose in $\mathrm{CV}$ rats and decreased in GFAu rats. The main modification was the considerable reduction in iron absorption and retention in GF rats fed the Au diet (GFAu and GFAuL lots as compared to GFI and GFIL lots).

b) On the contrary, lactose greatly enhanced the absorption and retention of manganese. Steam sterilization did not reduce lactose effectiveness. Other modifications were minor. The presence of a flora decreased the retention and apparent absorption of manganese. L-S interaction was low and resulted mostly from the high values of the GFI lot. Lactose thus appeared to have a simple effect on manganese.

In all other cases, lactose action was accompanied by interaction with the flora, the mode of sterilization, or both of these factors simultaneously.

c) The effect of lactose on copper was characterized by L-S inferaction ; the IL diet enhanced absorption and retention of copper, while AuL had an unfavorable effect.

Moreover, GF rats absorbed more copper, and excreted more of it by the urinary route than $C V$ rats ; copper retention, however, was higher in GF rats.

d) Zinc, calcium and phosphorus had the same property : when the diet was irradiated, lactose increased their retention only in CV rats. However, there were some differences among these minerals.

The lactose increased the very low values of zinc retention and apparent absorption in $\mathrm{CV}$ rats to levels equal to or higher than those of GF rats (F-L interaction), whether the diet was steam-sterilized or irradiated. As in the case of zinc, the values of calcium retention and apparent absorption were lower in CV than in GF rats, Lactose only elevated these levels in CV rats. However, this lactose effect was only found with the I diet and disappeared when the Au diet was given; a decrease occurred even in the GF animals (lot GFAuL).

The variation of phosphorus retention was similar to that of calcium, but the situation was more complicated because retention did not only change according to absorption variation, but also with the modulations in urinary excretion 


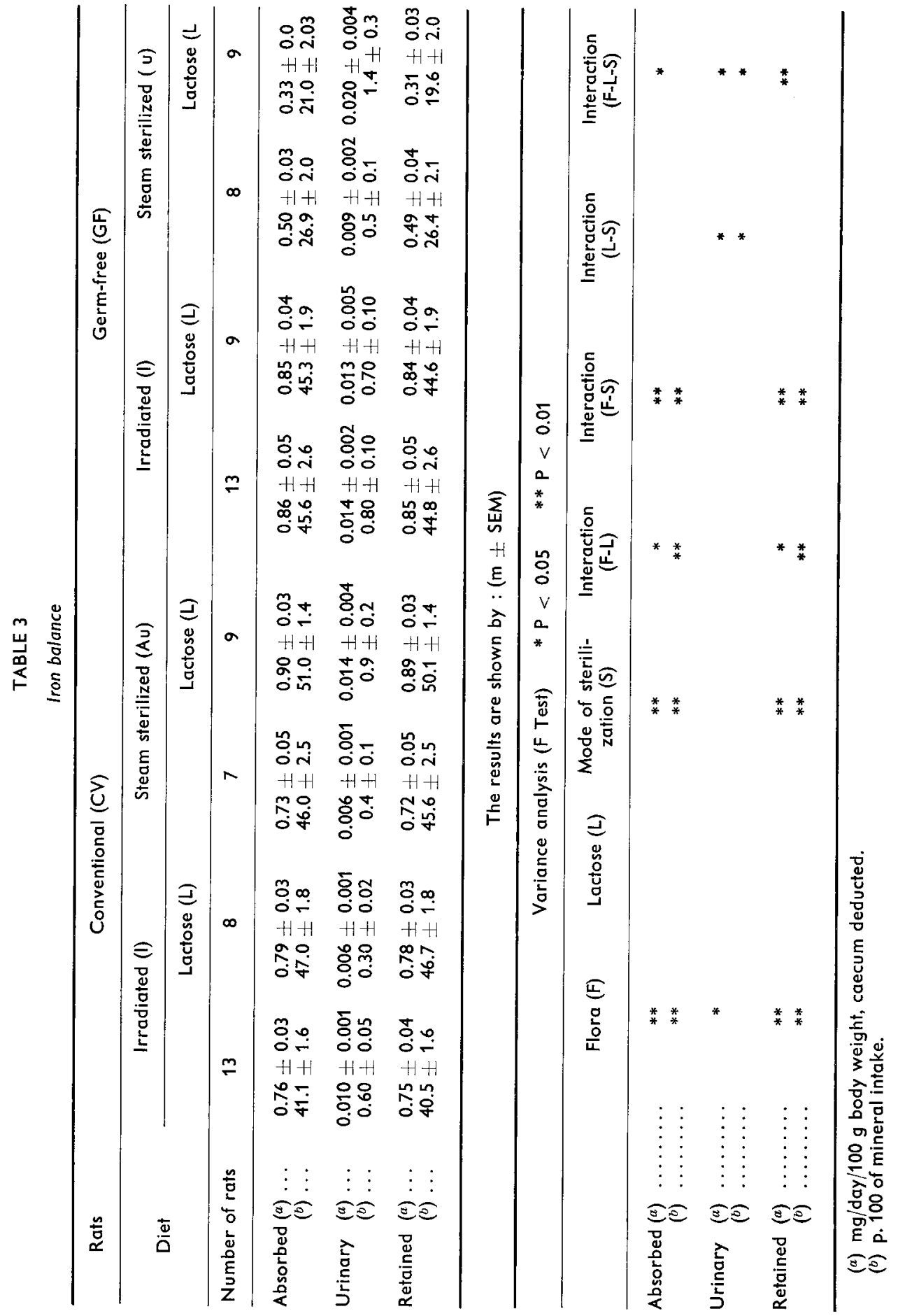




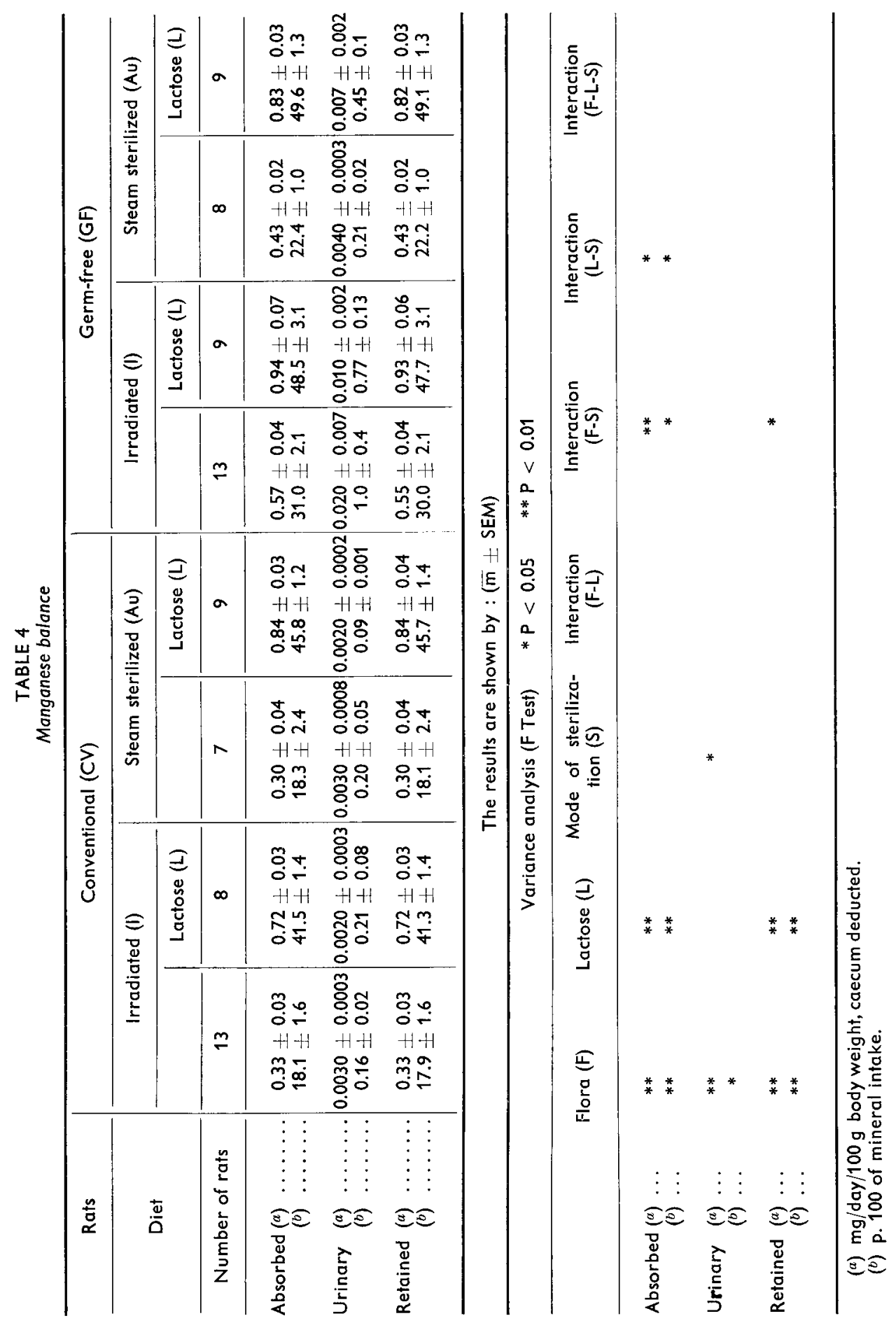




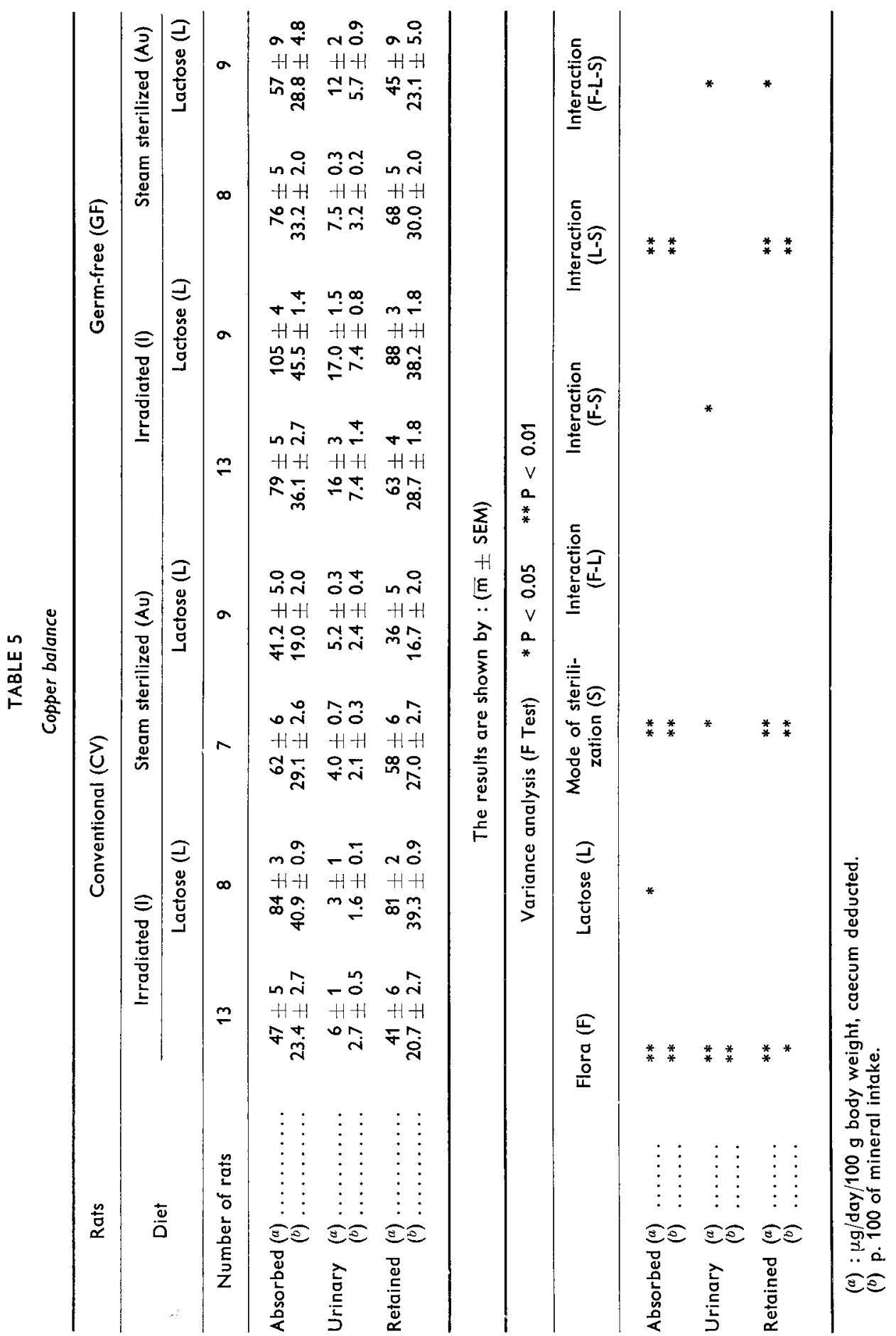




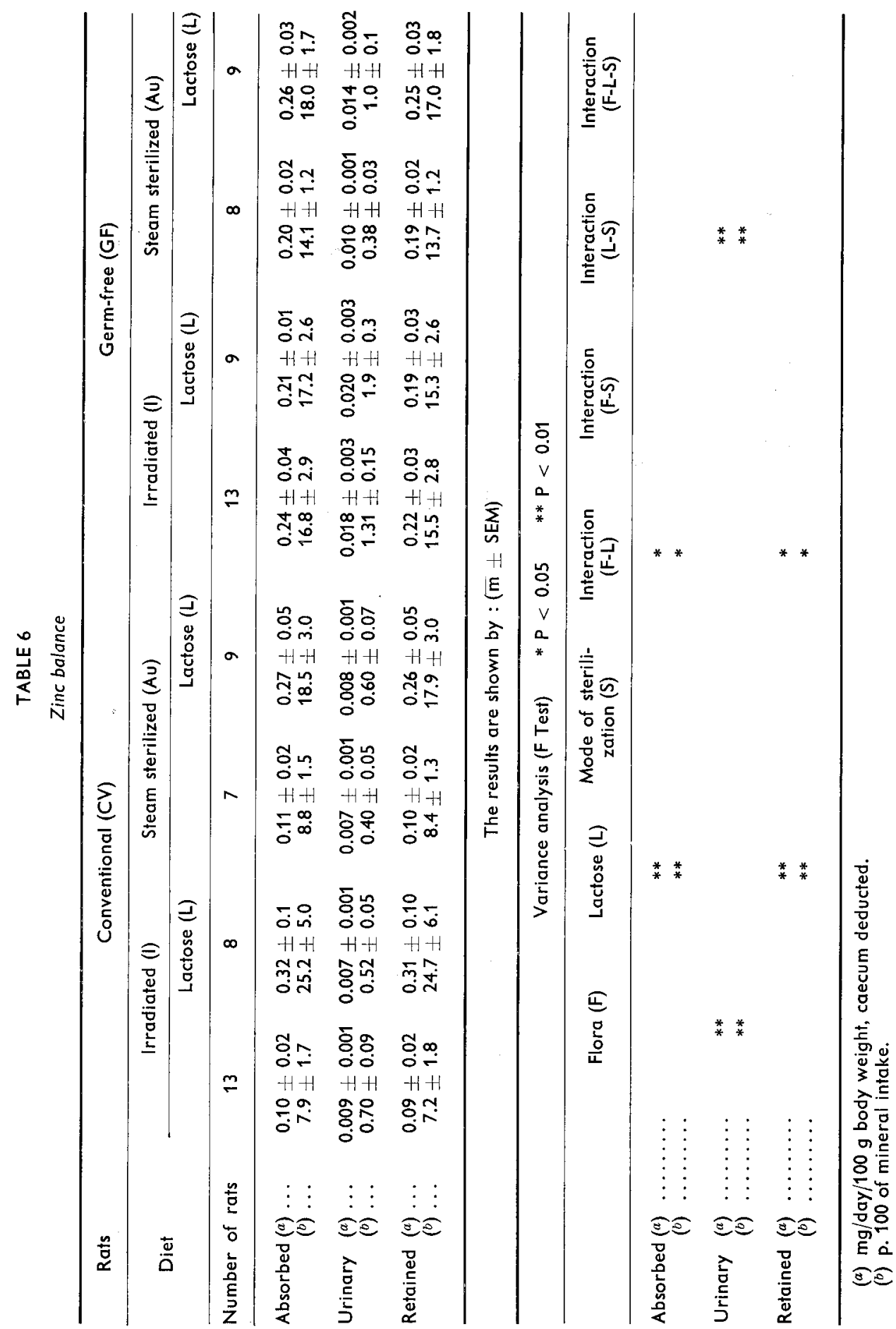




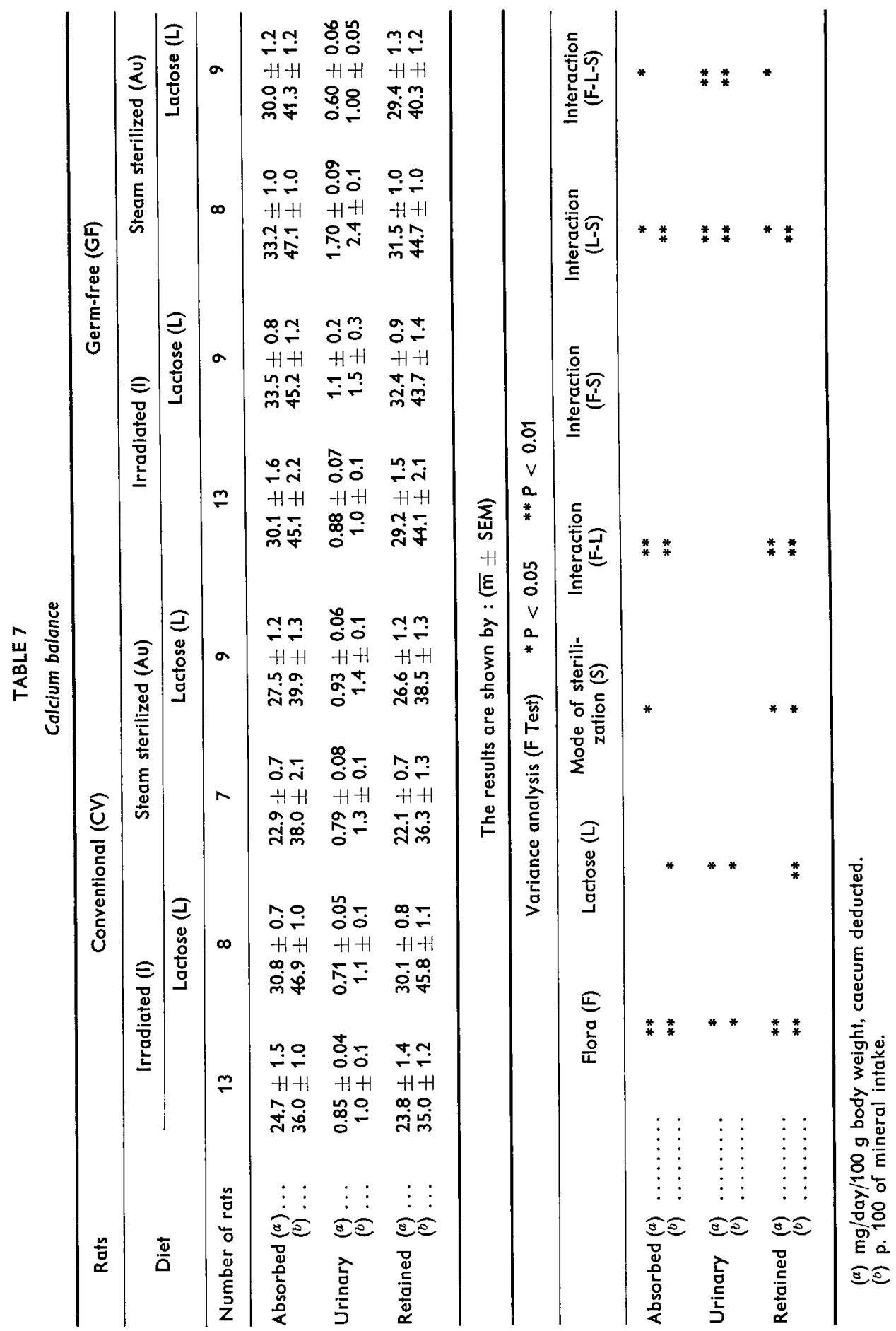




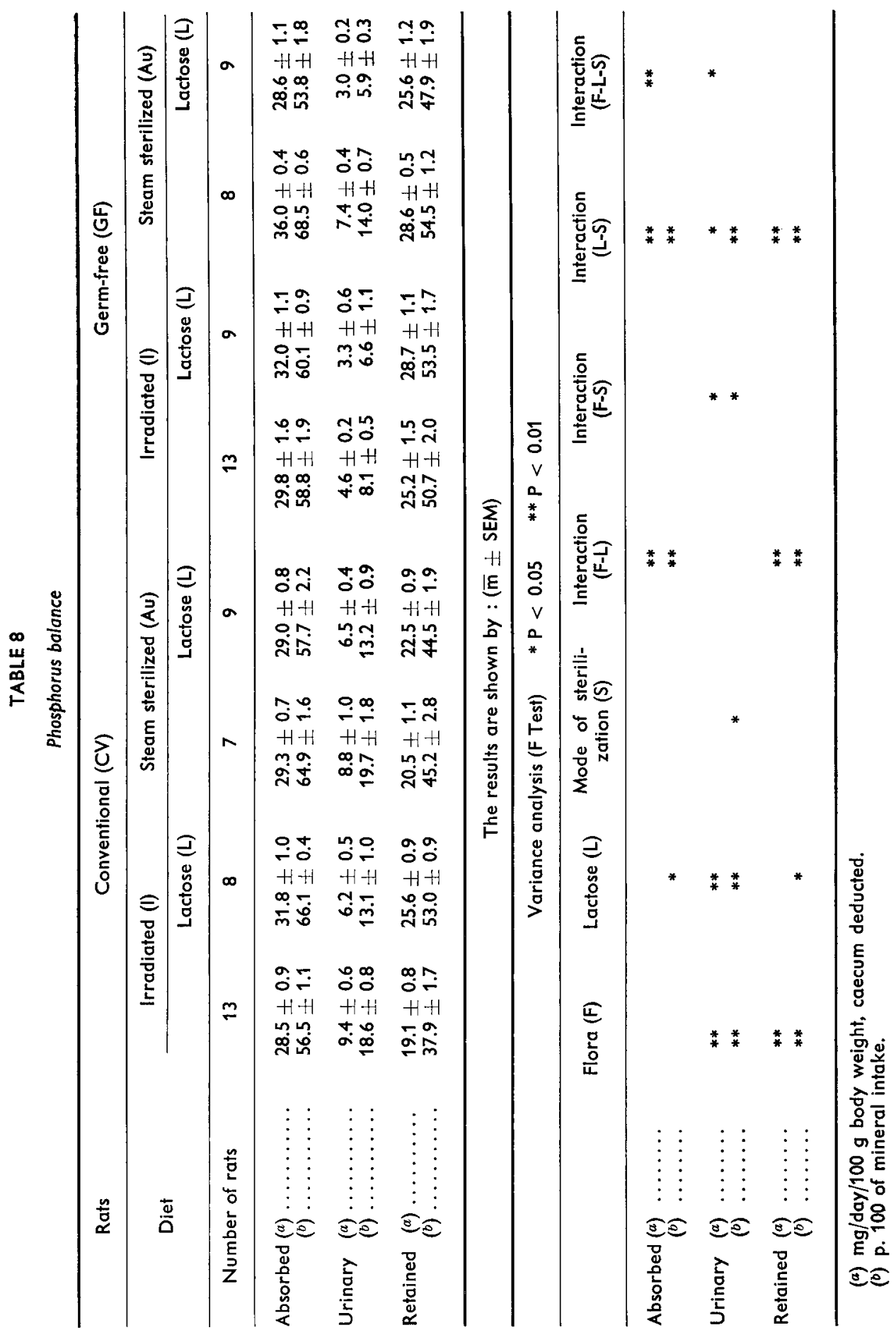




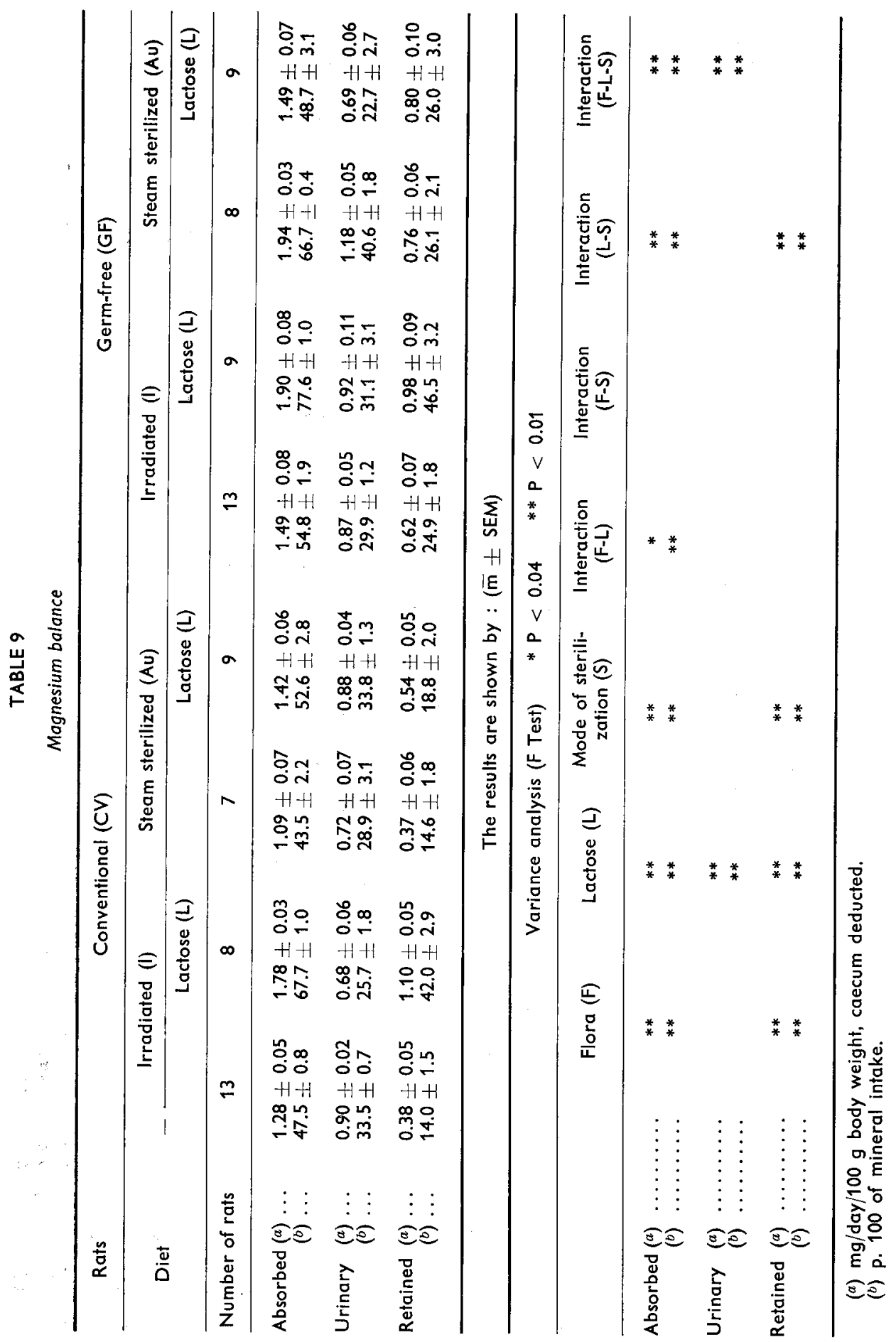




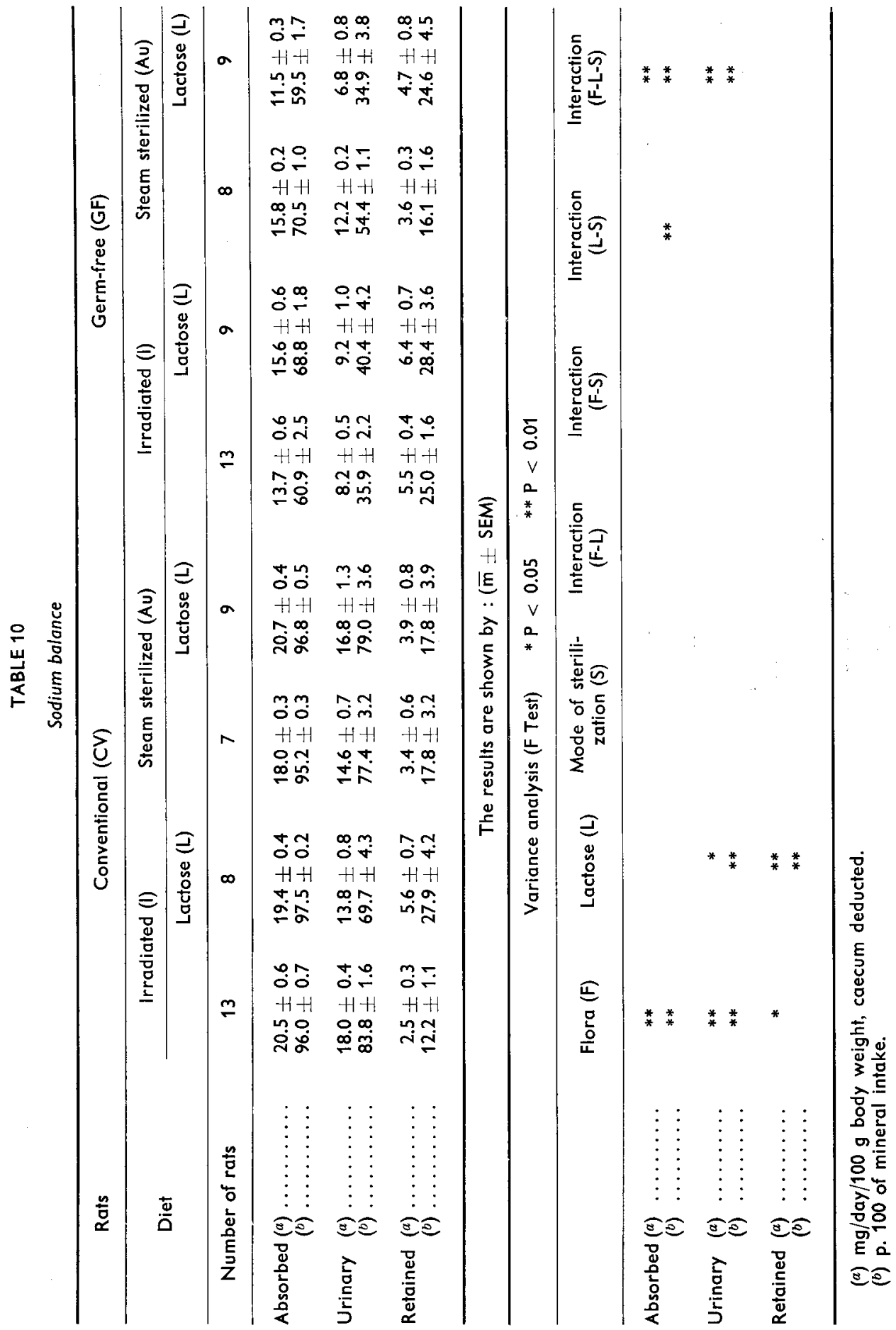




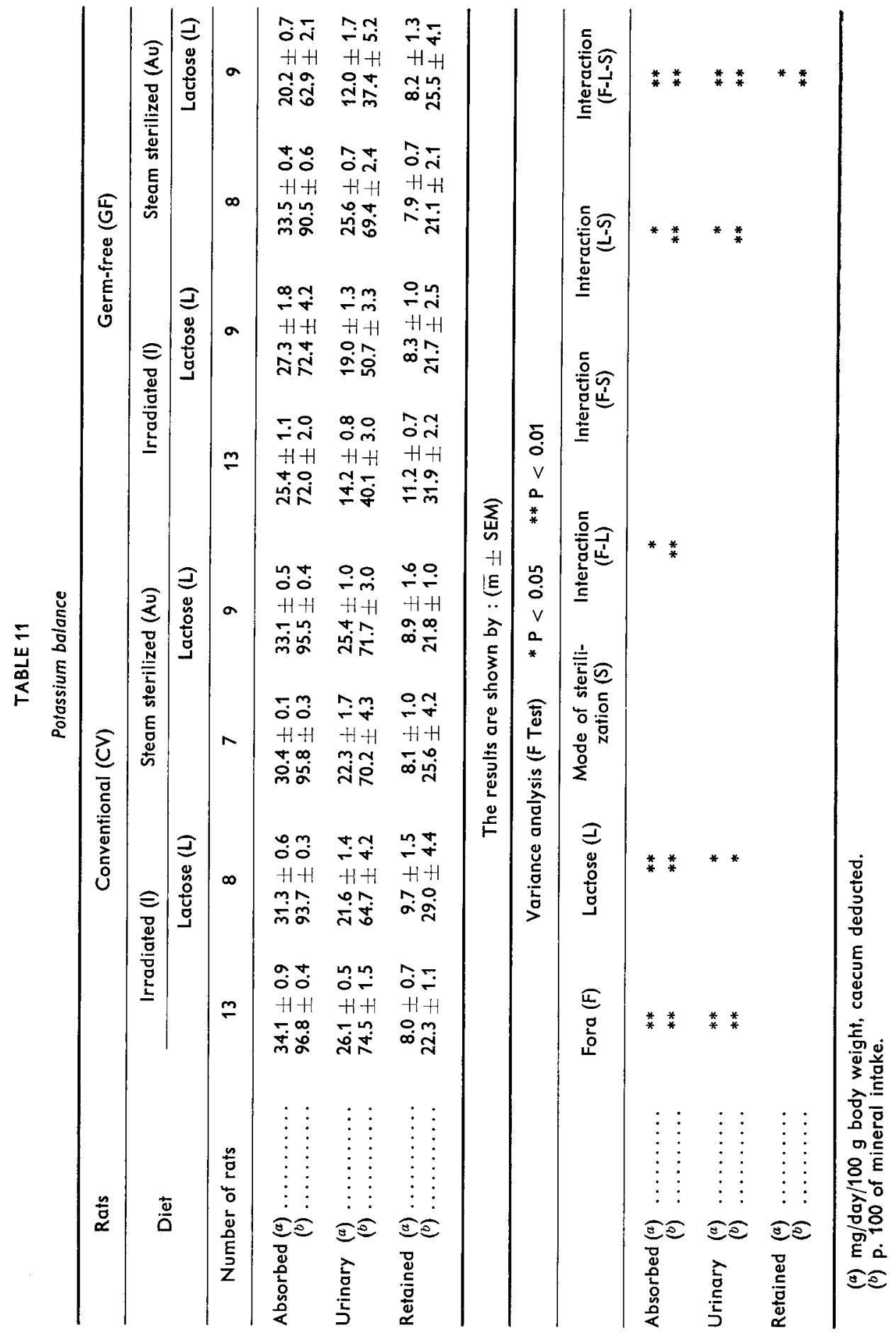


Apparent absorption of $\mathrm{P}$ was similar in $\mathrm{CV}$ and GF rats fed a lactose-free diet, and it was higher in animals given the Au dief than in those fed the I diet. Lactose enhanced apparent phosphorus absorption in CV rats fed the irradiated diet (IL), but it did not change this factor in GF rats fed the same diet. On the other hand, phosphorus absorption decreased in GF and CV animals receiving the AuL diet. Urinary phosphorus excretion was lower in GF than in CV rats and in rats fed a lactose diet as compared to those receiving a lactose-free ration. The effect of these interactions on apparent absorption and urinary excretion was that lactose enhanced phosphorus retention more in $C V$ than in GF rats ( $F-L$ interaction), and that retention increased in rats fed the IL diet, while it decreased in those fed the AuL diet (L-S interaction).

e) The effects of flora, lactose and mode of sterilisation on the last group of minerals (magnesium, sodium, potassium) were more complicated.

The absence of microbial flora, the presence of lactose, and sterilization by irradiation augmented the retention and apparent absorption of magnesium ; the most important characteristic was the L-S interaction. The IL diet enhanced magnesium retention, but this effect disappeared or decreased strongly when the diet was steam sterilized (AuL). The IL effect was mainly due to increased apparent absortion. The absence of the AuL effect was not a result of invariable absorption ; absorption did decrease in GF rats (GFAuL as compared to GFAu), but it was compensated for by a considerable decline of urinary excretion in GFAuL rats ; on the other hand, in $C V$ rats absorption and urinary excretion tended to increase under the influence of $A u$.

The lack of microbial flora considerably decreased sodium absorption, and this is a very important fact. However, the presence of lactose and the mode of diet sterilization also played a role. Retention tended to increase in GF rats fed the AuL diet and in CV rats eating the IL diet. In the former (lot GFAuL), absorption declined and there was less urinary excretion ; in the latter (lot CVAuL), only urinary excretion dropped.

The absence of microbial flora diminished apparent absorption of $\mathrm{K}$ more in lot GFI animals than in those of lot GFAu. The lactose in the AuL diet caused a considerable drop in apparent absorption of potassium in lot GFAuL rats. These variations in absorption were compensated for by some reverse variations in urinary excretion, so that potassium retention was unmodified in GF animals fed the Au diet. Variations in potassium retention in the different experimental lots were complex, but not very wide.

Thus, dief IL tended to increase the retention of most of the minerals, sometimes $(\mathrm{Na}, \mathrm{Zn}, \mathrm{P}, \mathrm{Ca})$ only in GF animals, and at other times $(\mathrm{Mn}, \mathrm{Mg}, \mathrm{Cu})$ in both $\mathrm{GF}$ and $\mathrm{CV}$ rats. Steam sterilization of the lactose (AuL) largely decreased this effect and even reversed it, except as concerned $\mathrm{Zn}$ and $\mathrm{Mn}$.

These variations in retention caused by the AuL or IL diet, were due to modification in absorption in the case of $\mathrm{Ca}, \mathrm{Cu}, \mathrm{Mn}$ and $\mathrm{Zn}$. They were due both to modifications of absorption and urinary excretion in the case of $\mathrm{P}, \mathrm{Mg}, \mathrm{Na}$ and $\mathrm{K}$.

\section{Discussion.}

Lactose increases the caecal weight of CV rats (Fisher, 1957 ; Fournier, Susbielle and Bescol-Liversac, 1959 ; Février and Rérat, 1964 ; Adrian and Frangne, 1978 ; Leegwater, De Groot and Van Kalmthout-Kuyper, 1974 ; Kyu-ll Kim, Benevenca 
and Grummer, 1978 ; Pansu, Bellaton and Bosshard, 1978). In our experiment, this weight increase was only significant under the action of steam-sterilized lactose (AuL); the same effect was also found in GF rats. Thus, the role of microbial flora in this action could not be affirmed.

The fact that the AuL died reduced diet digestibility more in GF than in CV rats, and thus that the microbial flora palliated this unfavorable effect, is a new factor meriting further investigation. The elements of fecal excretion increasing in GF rats, and the microbial flora processes causing the digestion and absorption of these elements, remain to be determined.

Our present knowledge only partially explains the variations of mineral metabolism which are induced by IL or AuL. Although irradiating the ration modified it somewhat, we believe that the IL effect was mainly due to the presence of lactose in the diet; it has been confirmed that irradiation does not modify dietary lactose level. Lactose generally increases calcium absorption in CV rats, but authors have offered various hypotheses to explain this action mechanism (Ali and Evans, 1973) : formation of the lactose-calcium complex (Charley and Saltman, 1963), modification of the mucosa cell membrane potential (Martin and De Luca, 1969), inhibition of absorption control and neutralization of calcium absorption inhibitors (Wasserman, 1964), increased enterocyte cell permeability (Armbrecht and Wasserman, 1976). Fournier and his collaborators explain better calcium absorption, due to the effect of some carbohydrates, by the fact that the carbohydrates are phosphorylable. Phosphate ion fixation on carbohydrates would permit the calcium transport mechanism implicating alkaline phosphatase to function longer. It would also prevent the formation of insoluble calcium phosphate. These authors use the same hypothetical mechanism to explain the effects of some sugars, such as lactose, on the absorption of manganese, zinc and cobalt and minerals having insoluble phosphates (Dupuis, Digaud and Fournier, 1978).

However, none of these hypotheses explain why dietary lactose has no effect on the retention and apparent absorption of calcium in GF rats.

Reddy (1972) showed that calcium-binding protein (CaBP), Ca+-ATPase, and alkaline phosphatase are more active in GF than in $\mathrm{CV}$ rats. This more intense activity would be the result of a higher synthesis of these substances in the GF rat enterocyte, If, as Fournier thinks, the role of lactose is to prolong the action of alkaline phosphatase, there is no reason why it should not also act in GF rats. On the other hand, this lactose effect, occurring mostly in the lower part of the small intestine (Dupuis, Digaud and Fournier, 1978), may not appear because it is masked by very high $\mathrm{Ca}$ absorption in the upper small intestine of GF rats. According to Dupuis and Fournier (1964), the effect of lactose is greater in rats older than 3 months than in younger ones. The differences observed between germfree and conventional rats in this experiment are to be confirmed in older rats.

Mechanisms other than a change in the transport systems could explain the modification caused by the presence or absence of microbial flora.

The lactic fermentation could act directly by forming lactates which would prevent the formation of insoluble salts. Lactobacilli are already present in the rat stomach in large amounts (Raibaud ef al., 1966). 
Finally, lactic fermentation might completely transform the digestive tract microbial flora and, for instance, bacteria which fix calcium or produce calcium absorption inhibitors might disappear. This lactose effect on the flora was shown in cellulose digestion (Février, Collet and Bourdon, 1973) and in bile acid metabolism which decrease in CV rats fed lactose (Wostmann ef al., 1976).

Steam-sterilizing the lactose diet has a twofold effect : it decreases dietary lactose content from 10 to 6.6 p. 100 , and causes reactions among the lactose and the other dietary components, especially the amino acids. Maillard reaction products are formed, as shown by a browning of the AuL diet. The AuL treatment thus has complex effects on diet composition. In the present experiments, it is impossible to differentiate the modifications in mineral metabolism due to a decrease of lactose during steamsterilization from those caused by the action of Maillard reaction products. In some cases, the decrease in absorption suggests that this change is the true result of the action of these products rather than the result of a $1 / 3$ decrease in the lactose content of the diet. This is the case of phosphorus and copper in CV and GF rats and of magnesium, sodium and potassium in GF animals only. It is probably true also for iron in GF rats because, although iron absorption decreases little under AuL action, IL does not increase absorption. Also, aside from their possible effect on minerals, there is no doubt that Maillard reaction products do increase fecal excretion and decrease the dDER of dry matter spectacularly in lot GFAuL.

It is still more difficult to determine how much microbial flora modulate the effect of these Maillard reaction products on mineral metabolism. Further expérimentation is necessary to define this relationship. Such an event might take place in magnesium absorption and urinary excretion, and it is a fact as concerns fecal excretion and the apparent digestibility of dry matter.

Since AuL augments the fecal excretion of dry matter and decreases sodium and potassium absorption, further research is necessary to determine if it increases mucoprotein formation. Asano (1967) and Gordon and Wostmann (1973) reported that negatively charged mucoproteins which accumulate in the GF rat caecum, caused a paucity of $\mathrm{Cl}-$ ions and decreased water resorption ; this action would be accompanied by a decrement of caecal sodium and potassium absorption. Naturally, these effects are not found in CV rats since the microbial flora hydrolyse the mucoproteins.

\section{Conclusion.}

Lactose action on rat mineral metabolism is complex and varies with the mineral ; it is not necessarily similar in GF and CV rats, and is considerably changed by the mode of diet sterilization.

The irradiated lactose diet increased the retention of most minerals, i.e. $\mathrm{Mn}$, $\mathrm{Mg}, \mathrm{Cu}$ in $\mathrm{CV}$ and $\mathrm{GF}$ rats ; $\mathrm{Na}, \mathrm{Zn}, \mathrm{P}, \mathrm{Ca}$ in $\mathrm{CV}$ rats only.

Steam sterilization of the lactose diet caused a reduction, or even a reversal, of the favorable effect of lactose on apparent absorption of minerals. The decrease in dietary lactose content could not explain the differences observed between IL and AuL effects, and it is probable that other factors, such as the Maillard reaction products formed during steam sterilization, play a role. We found little evidence of microbial 
flora affecting the action of the AuL diet on mineral metabolism. On the other hand, the effect of the flora was clear in relation to diet digestibility, which was lower in GF than in CV rats fed the AuL diet.

Reçu en avril 1979. Accepté en juillet 1979.

Acknowledgments. - We wish to thank Mr. Ley of the Laboratoire de Biométrie, INRA (Jouy-en-Josas), who did the statistical analysis of the data, and Mr. Hemme of the Laboratoire de Biochimie microbienne, INRA (Jouy-en-Josas), who analysed the lactose content of the diet. This study received a grant from the DGRST (contract $n^{0}$ 77-7-0475).

Résumé. Des bilans minéraux $(\mathrm{Ca}, \mathrm{P}, \mathrm{Mg}, \mathrm{K}, \mathrm{Na}, \mathrm{Zn}, \mathrm{Mn}, \mathrm{Fe}, \mathrm{Cu})$ sont réalisés sur des rats Fisher âgés de 6 semaines, pendant 14 jours consécutifs.Quatre lots de rats axéniques (GF) et quatre lots de rats holoxéniques (CV) reçoivent dès le sevrage un aliment semisynthétique contenant soit 0 , soif 10 p. 100 de lactose (L). L'aliment est soit stérilisé par irradiation (I), soit par autoclavage (Au).

L'addition de lactose à l'aliment provoque des modifications du métabolisme minéral très variables selon l'élément minéral considéré et le mode de stérilisation de l'aliment. Ainsi l'absorption apparente et la rétention de Fe sont peu modifiées par la présence de lactose. A l'opposé, celles de Mn sont fortement accrues par le lactose. Pour les autres minéraux, l'action du lactose est complexe ; elle est modifiée soit par le mode de stérilisation de l'aliment, soit par la flore, soit par les deux facteurs à la fois.

L'aliment $\mathrm{Ll}$ augmente la rétention de la plupart des minéraux : dans certains cas $(\mathrm{Na}, \mathrm{Zn}, \mathrm{P}, \mathrm{Ca})$, cette action ne s'exerce que chez les rats $\mathrm{CV}$, dans d'autres cas $(\mathrm{Mn}, \mathrm{Mg}$, Cu) elle s'exerce à la fois chez les rats CV et GF.

L'autoclavage du lactose (LAu) s'accompagne d'une réduction importante et même d'une inversion de cet effet. Cette altération de l'action du lactose sous l'effet de l'autoclavage porte surtout sur l'absorption, qui est diminuée pour tous les minéraux, sauf pour $\mathrm{Zn}$ et $\mathrm{Mn}$. Elle s'accompagne d'une diminution de l'utilisation digestive de la ration alimentaire, particulièrement prononcée chez les rats GF.

La réduction de $1 / 3$ du taux de lactose de l'aliment après stérilisation par autoclavage ne permet pas à elle seule d'expliquer les différences observées entre les effets LI et LAU. II faut supposer que d'autres facteurs interviennent, tels que les produits de la réaction de Maillard formés au cours de l'autoclavage de l'aliment.

\section{Références}

ADRIAN J., FRANGNE R., PETIT L., GODON B., BARBIER J., 1966. Répercussions nutritionnelles des produits solubles formés au cours de la réaction de Maillard. Ann. Nutr. Alim., 20, 257277.

ADRIAN J., 1974. Nutritional and physiological consequences of the Maillard reaction. World Rev. Nutr. Diet., 19, 71-122.

ADRIAN J., SUSBIELLE H., 1975. La réaction de Maillard. 10. Effets des prémélanoïdines sur la reproduction chez le rat. Ann. Nutr. Alim., 29, 151-158.

ADRIAN J., FRANGNE R., 1978. Rôle de la flore digestive dans l'adaptation du rat d̀ une alimentation lactosée. J. int. Vitaminol. Nutr., 48, 170-176.

ALI R., EVANS J. L., 1973. Lactose and calcium metabolism : A review., J. Agri. Univ. P. R., 57, 149. 164.

ANDRIEUX C., GUÉGUEN L., SACQUET E., 1979. Influence du mode de stérilisation des aliments sur l'absorption des minéraux chez le rat axénique et holoxénique. Ann. Nutr. Alim., 33, 1257 1284. 
ARMBRECHT H. J., WASSERMAN R. H., 1976. Enhancement of $\mathrm{Ca}^{++}$uptake by lactose in the rat small intestine. J. Nutr., 106, 1265-1271.

ASANO T., 1967. Inorganic ions in caecal content of gnotobiotic rats. Exp. Biol. Med., 124, 424-430.

BERGEIM O., 1926. Intestinal chemistry. $V$ : carbohydrates and calcium and phosphorus absorption. J. biol. Chem., 70, 35-45.

BOUVET D., 1970. Influence de la nature du composé glucidique ingéré simultanément avec le ${ }^{59} \mathrm{Fe}$ sur la rétention et l'utilisation de cet élément. C. R. Soc. Biol., 164, 2452-2455.

CHARLEY P. J., SALTMAN P., 1963. Chelation of calcium by lactose : its role in transport mechanisms. Science, 139, 205-206.

DUPUIS Y., 1957. Lactose et utilisation du calcium. Influence du lactose sur les échanges calciques ef sur le développement du squelette du rat en croissance soumis à diverses conditions alimentaires. C. R. Soc. Biol., 151, 1722-1725.

DUPUIS Y., BRUN P., FOURNIER P. L., 1962. Etude de l'activité du lactose, facteur exogène de l'utilisation du calcium en fonction de la dose administrée. C. R. Acad. Sci. Paris, 254, 2230-2232.

DUPUIS Y., DIGAUD A., FOURNIER P., 1978. Phosphatases alcalines intestinales et composés glucidiques dans leurs rapports avec l'absorption du calcium. Ann. Biol. anim. Bioch. Biophys., 18, 1129-1139.

DUPUIS Y., FOURNIER P. L., 1964. Etude comparée de l'action de la vitamine D et du lactose sur les échanges calciques durant la vie du rat. C. R. Acad. Sci. Paris, 258, 2906-2909.

FÉVRIER C., RÉRAT A., 1964. Influence du lactose sur la croissance et sur la composition corporelle du rat blanc. I. Relations avec le taux protidique de la ration. Ann. Biol. anim. Bioch. Biophys., 4, 423-439.

FÉVRIER C., COLLET J., BOURDON D., 1973. Utilisation de divers types de lactosérum dans les régimes de sevrage des porcelets et durant la période de croissance finition. Journ. Rech. porcine en France, Paris, INRA-ITP ed., 79.

FISHER J. E., 1957. Effects of feeding diets containing lactose upon $\beta$ D-galactosidase activity and organ development in the rat digestive tract. Am. J. Physiol., 488, 49-53.

FISHER J. E., 1957. Effects of feeding diets containing lactose, agar, cellulose, raw potato starch or arabinose on the dry weights of cleaned gastrointestinal tract organs in the rat. Am. J. Physiol., 188, 550-554.

FOURNIER P., 1954. Aperçus nouveaux sur la physiologie des glucides déduits de leur activité différente vis-à-vis de l'utilisation du calcium. C. R. Acad. Sci. Paris, 239, 718-720.

FOURNIER P., SUSBIELLE H., BESCOL-LIVERSAC, 1959. Influence de la nature des composés glu. cidiques ingérés sur le développement de diverses parties du tube digestif du jeune rat. C. R. Acad. Sci. Paris, 248, 2799-2881.

FOURNIER P., DUPUIS Y., 1964. Epaississement généralisé du squelette sous l'effet de l'administration continuelle de lactose. C. R. Acad. Sci. Paris, 258, 3089-3092.

FOURNIER P., DUPUIS Y., GAMBIER J., 1966. Influence d'une administration continue de lactose sur le poids, l'aspect et la composition des os du rat âgé. C. R. Acad. Sci. Paris, 262, 797-800.

FOURNIER P., DIGAUD A., 1969. Effets, chez le rat, de l'ingestion simultanée de lactose et de ${ }^{65} \mathrm{Zn}$ sur l'absorption et la rétention de cet élément. C. R. Acad. Sci. Poris, 269, 2001-2003.

FOURNIER P., FOURNIER A., 1972. Influence de l'ingestion de lactose sur l'absorption et la rétention du manganèse. C. R. Soc. Biol., 166, 29-31.

FOURNIER P., FOURNIER A., DIGAUD A., 1974. Augmentation chez le rat de l'utilisation de $\mathrm{Co}^{58} \mathrm{du}$ fait d'une ingestion simultanée de certains glucides. C. R. Soc. Biol., 168, 244-247.

FOURNIER P., DUPUIS Y., 1975. La modulation de l'absorption intestinale du calcium. J. Physiol. Paris, 70, 479-491.

GORDON H. A., WOSTMANN B. S., 1973. Chronic mild diarrhea in germfree rodents : a model for varying host-flora synergism, 593-601. In HENEGHAM J. B., Germfree research : Biological effect of gnotobiotic environments. Acad. press, New York et London.

GRUDEN N., 1976. The effect of milk diet on manganese transport through the rat's duodenal wall. Nutr. Rep. Int., 14, 515-520.

KYU-IL KIM, BENEVENCA N. J., GRUMMER R. H., 1978. Estimation of the fraction of the lactose in a high lactose diet available for fermentation in the caecum and colon of the rat. J. Nutr., 108, 79-89. 
LEEGWATER D. C., DE GROOT A. P., VAN KALMTHOUT-KUYPER M., 1974. The aetiology of caecal enlargement in the rat. Fd. Cosmet. Toxicol., 12, 687-697.

LEICHTER J., TOLENSKY A. F., 1975. Effect of dietary lactose in the absorption of protein, fat and calcium in the post weaning rat. Am. J. clin. Nutr., 28, 238-241.

LENGEMANN F. W., 1959. The site of action of lactose in the enhancement of calcium utilisation. J. Nutr., 69, 23-27.

LENGEMANN F. W., WASSERMAN R. H., COMAR C. L., 1959. Studies on the enhancement of radiocalcium and radiostrontium absorption by lactose in the rat. J. Nutr., 68, 443-456.

MARTIN D. L., DE LUCA H. F., 1969. Influence of sodium on calcium transport by the small intestine. Am. J. Physiol., 216, 1351-1359.

PANSU D., BELLATON C., BOSSHARD A., 1978. Effect of lactose feeding on cell renewal, disaccharidase activity and calcium binding protein content in the intestinal mucosa of rats. Ann. Biol. anim. Bioch. Biophys., 18, 127-132.

RAIBAUD P., DICKINSON A. B., SACQUET E., CHARLIER H., MOCQUOT G., 1966. La microflore du tube digestif du rat. II. Dénombrement de différents genres microbiens dans l'estomac et l'infestin des rats conventionnels. Variations quantitatives individuelles et en fonction de l'âge. Ann. Inst. Pasfeur, 110, 861-876.

REDDY B. S., 1972. Studies on the mechanism of calcium and magnesium absorption in germfree rats. Arch. Biochem. Biophys., 149, 15-21.

SACQUET E., RAIBAUD P., GARNIER H., 1971. Etude comparée de la microflore de l'estomac, de l'intestin grêle et du caecum du rat holoxénique et de ses modifications à la suite de diverses modifications chirurgicales : anse aveugle jéjunale, déviations biliaires. Ann. Inst. Pasteur, 120, $501-524$.

SCHEFFE H., 1959. The complete two, three and higher way layout, 90-137. In SCHEFFE H., The onalysis of variance. J. Wiley and sons, $N$. York.

TANAKA M., TUNG-CHING LEE, CHICHESTER C. O., 1975. Nutritional consequences of the Maillard reaction. The absorption of fructose $L$ tryptophan in large intestine of the rat. J. Nutr., 105, 989-994.

WASSERMAN R. H., 1964. Lactose-stimulated intestinal absorption of calcium : a theory. Nature, 201, 997-999.

WOSTMANN B., BRUCKNER-KARDOSS E., BEAVER M., CHANG L., MADSEN D., 1976. Effect of dietary lactose at levels comparable to human consumption on cholesterol and bile acid metabolism of conventional and germfree rats. J. Nutr., 106, 1782-1790. 